\title{
German Anti-Stalking Legislation and Its Recent Changes
}

\author{
Anni Ropers, Viola Ebner, Selina Burgard, Julia Zucker and Michael Erber*
}

(Accepted 28 November 2019)

\begin{abstract}
In 2013, 19,775 people were investigated for stalking. Of those nearly twenty thousand people, however, only a small fraction were convicted. This Article explores the methods employed under German law in striving to combat stalking (Nachstellung), the problems arising the refrom, and the most recent changes in stalking legislation. While numbers can illustrate the flaws of a seemingly malfunctioning system easily, identifying the causes and eradicating them is a more complex matter.
\end{abstract}

Keywords: Criminal law; anti-stalking legislation; $₫ 238$ StGB; current developments in German criminal law; Protection Against Violence Act

\section{A. Development of the Criminal Law}

Initially, it should be mentioned that the current legislation, mainly stipulated in the German Criminal Code (Strafgesetzbuch; StGB) and Protection Against Violence Act (Gewaltschutzgesetz; GewSchG), is relatively new to the majority of German statutory law and, as such, is still regularly undergoing modifications. The latest amendments to $₫ 238 \mathrm{StGB}$ came into force in March 2017.

For many years, stalking was often not recognized by the public as criminal behavior in need of legal regulation. Awareness of the subject was raised mainly through the media following incidents of harassment involving celebrities, often in other countries. The popular American actress Rebecca Schaeffer, for instance, was killed in 1989 by an obsessive fan, as was the British broadcaster Jill Dando in 1999. ${ }^{1}$ Both events created a new consciousness in the public eye for the problematic nature of continued and persistent obsessive behavior towards a person. The tragic consequences of Schaeffer's death even led to the development of the model anti-stalking legislation in America by the National Institute of Justice, which has since been adapted and adopted by most of the US states. ${ }^{2}$

Although these high-profile cases furthered the progress on the issue, they are the exceptions. It is just as likely for people who are not famous to become the target of unwanted attention and harassment. In fact, this form of obsessive behavior is often preceded by a relationship between the victim and perpetrator. The 2016 Police Report on Crime Statistics in Germany states that about

${ }^{\star}$ This article is the result of a group assignment as part of a legal English program for German students at the FriedrichAlexander-Universität Erlangen-Nürnberg. At the time, the authors were enrolled as law students at this university.

${ }^{1}$ The Nat'l Inst. of Justice, Annual Report to Congress Under the Violence Against Women Act 10; The Police Foundation, The Briefing Series 1, 2 (6th ed. 2009).

${ }^{2} I d$. at 10

(C) The Author(s), 2020. Published by Cambridge University Press on behalf of the German Law Journal. This is an Open Access article, distributed under the terms of the Creative Commons Attribution licence (http://creativecommons.org/licenses/by/4.0/), which permits unrestricted re-use, distribution, and reproduction in any medium, provided the original work is properly cited. 
forty-two percent of the stalking cases in Germany had been preceded by intimate relations between the parties. ${ }^{3}$ The examples of Schaeffer and Dando also illustrate a different issue. In most instances, the perpetrator not only stalks, but also resorts to different offenses. Stalking culminating in a more serious crime does not usually lead to a conviction for stalking, but rather to one for coercion, inflicting bodily harm, or manslaughter. The stalking is then deemed to be a subsidiary offense. In conjunction with this, the low number of convictions for stalking cannot necessarily be explained by a failure of the judiciary.

There are circumstances, however, which can only be solved by passing legislation specifically created for the problem of stalking. The legislation must sufficiently shield victims and prevent further harm. Recognizing the need to modernize German law to prevent domestic violence, the Gewaltschutzgesetz came into force in 2002. It currently contains four sections and aims to strengthen the claims the victim has against the perpetrator in civil proceedings and, furthermore, advances the ability to sanction violations under criminal law. The Gewaltschutzgesetz was, incidentally, the first and only legal provision to convict somebody for actions constituting stalking. Nevertheless, it was soon deemed an inadequate method of protecting stalking victims, which led to the German Criminal Code's amendments to render stalking punishable in the same way that other offenses are. This amendment came into force in March 2007 as the new $\$ 283$ StGB and was worded as follows:

\section{$\$ 238$ Stalking}

(1) Whosoever unlawfully stalks a person by

1. seeking his proximity,

2. trying to establish contact with him by means of telecommunications or other means of communication or through third person,

3. abusing his personal data for the purpose of ordering goods of services for him or causing third persons to make contact with him,

4. threatening him or a person close to him with loss of life or limb, damage to health or deprivation of freedom, or

5. committing similar acts and thereby seriously influences his lifestyle shall be liable to imprisonment not exceeding three years or a fine.

(2) The penalty shall be three months to five years if the offender places the victim, a relative of or another person close to the victim in danger of death or serious injury.

(3) If the offender causes the death of the victim, a relative of or another person close to the victim the penalty shall be imprisonment from one to ten years.

(4) Cases under subsection (1) above may only be prosecuted upon request unless the prosecuting authority considers propio motu that prosecution is required because of special public interest. ${ }^{4}$

\section{B. Structure of $\S 238$ StGB}

\section{Basic Facts}

Pursuant to $₫ 238$ I StGB, unlawful stalking that seriously affects the victim’s lifestyle is a criminal offense punishable with a fine or with a term of imprisonment not exceeding three years. ${ }^{5}$ The following passage will describe in greater detail the factual preconditions necessary to constitute the criminal offense.

\footnotetext{
${ }^{3}$ Bericht ZUR POLIZEILICHEN KRIMINALSTATISTIK [PKS] 2016, Band 2, p.29.

${ }^{4}$ Strafgesetzbuch [STGB] [Penal CODE], $₫ 238$, translation at https://www.gesetze-im-internet.de/englisch_stgb/ englisch_stgb.html\#p1986 (Ger.).

${ }^{5}$ Andreas Schandl, Stalking: $\$ 238$ StGB - Fluch oder Segen für die Rechtspraxis? 176 (2014).
} 


\section{Stalking}

Even though the English word "stalking" is a widely accepted anglicism that has long made its way into the German vocabulary, ${ }^{6}$ the German legislature chose to speak of beharrliche Nachstellung, ${ }^{7}$ which can be translated as a persistent following or pestering of somebody. This results in two factual preconditions, namely the actual action of pestering and following the offender takes towards the victim (Nachstellung) and the persistence of the action (Beharrlichkeit), which cumulatively constitute stalking. ${ }^{8}$ The different forms of actions and behavior that can be subsumed under the German term Nachstellung are described in greater detail in $\$ 238$ I StGB, Nos. 1-5. ${ }^{9}$

According to the German legislature's official justification for the law, Beharrlichkeit (persistency) is supposed to require continuous or repeated behavior, which is not automatically demonstrated by virtue of mere repetition. ${ }^{10}$ Rather, what is required is for the act in question to display a certain degree of obstinacy and a high degree of indifference towards the statutory prohibition, which at the same time indicates the increased danger of committing further offenses. ${ }^{11}$ It is also necessary for the offender to not only act with disregard or indifference towards the opposing wishes of the victim, but also to possess no intention of changing the behavior in the future. ${ }^{12}$

\section{Unlawful}

According to the legislature, another factual precondition for the offense is that the act of stalking has to be unbefugt (unlawful). This means that explicit or implicit consent on the part of the victim - or a person acting on the basis of official or private entitlements or permission-precludes any liability for the offender. ${ }^{13}$

\section{Serious Influence on the Victim's Lifestyle}

The offense was drafted to be an Erfolgsdelikt (result crime). ${ }^{14}$ Therefore, the conduct of the acts pursuant to $\$ 238$ I Nos. 1-5 StGB must result in the forced impairment of the life of the victim. ${ }^{15}$ That can routinely be assumed whenever the victim has to change their habitual way of life as a consequence of the perpetrator's stalking. ${ }^{16}$ This means, for example, that the victim rarely leaves the house, only leaves under protective precautions, actively avoids certain places, limits social contacts, or, in extreme cases, feels forced to move houses or change jobs. ${ }^{17}$ An impairment is serious when it puts an objectively substantial burden on the victim, which significantly goes beyond any average, regularly acceptable, or reasonable impairment. ${ }^{18}$ In this way, the criminal offense neither protects those who are over-anxious, nor excludes those who are particularly obdurate and are barely influenced at all by the stalking. ${ }^{19}$

\footnotetext{
${ }^{6}$ Susanne Sadtler, Stalking - Nachstellung: Entwicklung, Hintergründe und Rechtliche HANDLUNGSMÖGLICHKEITEN 24 (2009); SCHANDL, supra note 5, at 30.

${ }^{7}$ SCHANDL, supra note 5, at 176.

${ }^{8}$ Helmut Fünfinn, Rechtliche Gestaltung des Stalking 114 (2010).

${ }^{9}$ Michael Markus Aul, Stalking - Phänomenologie und strafrechtliche Relevanz 182 (2009); SAdTler, supra note 6 , at 293 .

${ }^{10}$ Bundestag-Drucksache 16/575 p.7; SCHANDL, supra note 5, at 189; Aul, supra note 9, at 185.

${ }^{11}$ Bundestag-Drucksache 16/575 p.7; SCHANDL, supra note 5, at 189; AUL, supra note 9, at 185.

${ }^{12}$ Bundestag-Drucksache 16/575 p.7; SCHANDL, supra note 5, at 189.

${ }^{13}$ SCHANDL, supra note 5, at 196-197; AUL, supra note 9, at 186.

${ }^{14}$ Stephan-Georg Zacharias, Der Unrechtstatbestand Der Nachstellung ( $\$ 238$ StGB) IM Lichte Des STRAFRECHTLICHEN BESTIMMHEITSGRUNDSATZES 226 (2015).

${ }^{15}$ Aul, supra note 9 , at $186-187$.

${ }^{16} I d$. at 187.

${ }^{17}$ ZaCHARIAS, supra note 14, at 227; MATTHIAs KRÜGER, STALKING ALS STRAFTATBESTAND 183-90 (2007); FÜNFSINN, supra note 8 , at 117 .

${ }^{18}$ Andreas Mosbacher, Nachstellung - $\$ 238$ StGB, NeUE ZeITSChrift FÜr STRAFRECHT [NSTZ] 667 (2007).

${ }^{19}$ FÜNFSINN, supra note 8 , at 115 .
} 


\section{Subjective Elements}

The offense further requires a subjective element-mens rea-namely Eventualvorsatz (conditional intent to commit the crime). ${ }^{20}$ This includes the perpetrator's intention to seriously impair the victim's lifestyle, which may be difficult to prove through the rules of evidence. ${ }^{21}$

\section{Qualification}

The qualification in $\$ 238$ II StGB becomes relevant with the condition that there is a definite risk to the victim, a close relative, or a person close to the victim of being killed or seriously injured through the perpetrator's actions. ${ }^{22}$ Seriously injured in this context means a protracted and severe illness or a lengthy and considerable impairment of the ability to participate in the workforce. ${ }^{23}$ This definition also includes dangerous stalking methods and panic reactions of persecuted victims, as well as the impact of considerable psychological pressure which might result in depression, self-destructive actions-such as pill or drug abuse-or even suicide. ${ }^{24}$

\section{Stalking Resulting in Death}

The offense of stalking resulting in death, as stipulated in $₫ 238$ III StGB, occurs when the offender, through one of their actions, causes the death of the victim, a close relative, or someone close to the victim while being, at the very least, negligent regarding the death. ${ }^{25}$

\section{Criticism}

Since it came into force, the anti-stalking legislation has-especially in legal literature and teaching-been the target of stark criticism. ${ }^{26}$

\section{The Necessity of a Separate Stalking Offense}

A number of critics already refute the need for the punishment of so-called mild stalking; they claim that it is merely harassment, not a violation of a legally protected right. ${ }^{27}$ They accuse the legislature of symbolic legislation and actionism, which endangers an important principle that criminal law should always act as the ultima ratio and, therefore, can only offer fragmentary and subsidiary legal protection. ${ }^{28}$ Other critics recognize the punishability of stalking as a matter of principle, but would have preferred a reform or tightening of the already existing Gewaltschutzgesetz instead of a new section in the StGB. ${ }^{29}$

\section{Compliance with Article 103 /I GG}

Additionally, some citics question whether the norm satisfies the constitutional principle of legal certainty. ${ }^{30}$ Article 103 II GG states that an act can only be punished if the punishability of the act

\footnotetext{
${ }^{20}$ Mosbacher, supra note 18 , at 669.

${ }^{21}$ Mosbacher, supra note 18 , at 669.

${ }^{22}$ SCHANDL, supra note 5, at 210.

${ }^{23} I d$. at 210; Mosbacher, supra note 18 , at 669.

${ }^{24}$ Mosbacher, supra note 18 , at 669.

${ }^{25} \mathrm{Id}$. at 669.

${ }^{26}$ SADTLER, supra note 6, at 346; SCHANDL, supra note 5, at 237.

${ }^{27}$ SCHANDL, supra note 5, at 238.

${ }^{28}$ KRÜGER, supra note 17, at 92; SCHANDL, supra note 5, at 238, 243.

${ }^{29}$ SCHANDL, supra note 5, at 247-248.

${ }^{30}$ ZACHARIAS, supra note 14, at 307; SCHANDL, supra note 5, at 273.
} 
was determined by law before the offense was committed. ${ }^{31}$ Section 238 StGB contains some indistinct legal terminology, such as the factual preconditions of unlawful and persistent. ${ }^{32}$

Furthermore, the fact that $\$ 238$ I No. 5 StGB summarizes similar acts (andere vergleichbare Handlungen) under the factual preconditions of stalking constitutes a catch-all element. ${ }^{33}$ A number of legal scholars, therefore, consider the provision to be unconstitutional and push for a new version of the law with more precise legal terminology and no catch-all clause. ${ }^{34}$ Others argue that the legal concepts that require interpretation, as well as general clauses, are not generally prohibited in criminal law, and that-especially in the case of the anti-stalking legislation-this abstractness is necessary to grasp all the peculiarities of the individual case. They therefore do not question the constitutionality of $₫ 238$ StGB. ${ }^{35}$

\section{Psychological Impacts and Aspects of $\S 238$ StGB}

In order to fulfill the elements of the offense under $\$ 238 \mathrm{StGB}$, the perpetrator's actions must seriously infringe upon the victim's lifestyle. ${ }^{36}$ In order to obtain legal protection, the victim's regular behavior and style of living must be severely affected by the perpetrator's harassment. If the victim, however, decides to simply ignore the perpetrator's actions, even if they are extremely invasive and intimidating, the elements of the crime will not be fulfilled and sanctions will not follow. The victim must prove that their lifestyle has been seriously intruded upon, because the mere attempt to commit stalking is not punishable. ${ }^{37}$ Consequently, criminal liability is neither based solely upon the perpetrator's behavior nor on the behavior's criminality: The reaction of the victim is of major significance.

\section{Impact on the Victim's Mental and Physical Health}

This sole focus on the victim's reaction can cause numerous difficulties and even inhibit stalking victims from receiving comprehensive legal protection. For instance, one crucial factor that is often disregarded is that every act of stalking may result in a massive impact on the victim's mental and physical health, which can cause long-term medical conditions and psychological sequelae, even if the victim appears unperturbed on the outside.

By constantly following or pestering the victim, the perpetrator generates a mental strain that often results in the most common consequence of stalking, a permanently stressful situation for the victim. ${ }^{38}$ Due to a perpetrator's constant attempts to terrorize and the inability of the victim to control the situation, a victim is at a great risk of both losing self-confidence and giving up hope of a life without perpetual fear. ${ }^{39}$ The unpredictability of the perpetrator's behavior leaves the victim

\footnotetext{
${ }^{31}$ ZACHARIAS, supra note 14, at 291-292; SCHANDL, supra note 5, at 273.

${ }^{32}$ KRÜGER, supra note 17, at 179-180; ZACHARIAS, supra note 14, at 307-308; SCHANDL, supra note 5, at 273.

${ }^{33}$ Zacharias, supra note 14, at 312; Mirjam Utsch, Strafrechtliche Probleme des Stalking 243 (2007); SCHand, supra note 5, at 274-275.

${ }^{34}$ Sascha Vander, Stalking - Aktuelle Entwicklungen und Tendenzen zur Schaffung eines speziellen Tatbestandes, 89

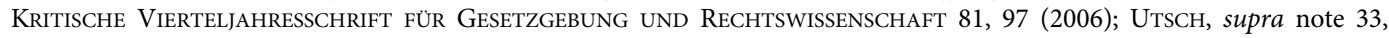
at 244; FÜNFSINN, supra note 8 , at 119.

${ }^{35}$ SCHANDL, supra note 5, at 276-277; SADTLER, supra note 6, at 363-364.

${ }^{36}$ Andreas Mosbacher, Notwendige Nachbesserungen bei der Nachstellung, ZeITSCHRIFT FÜR RECHTSPOLITIK [ZRP] 161 (2016).

${ }^{37}$ Andreas Mosbacher, Neuregelung der Stalking Strafbarkeit, NEUE JURISTISCHE WOCHENSCHRIFT [NJW] 983 (2017); Neuer Gesetzesentwurf zum Stalking, Neue JuRistische Wochenschrift SPEZIAL 538 (2016).

${ }^{38}$ Regierungsentwurf [Cabinet Draft], BUNDESRAT DRUCKSACHEN [BR] 193/14, at 5, https://www.bundesrat.de/SharedDocs/ drucksachen/2014/0101-0200/193-14.pdf?_blob=publicationFile\&v=1. (Ger.) [hereinafter Cabinet Draft 193/14].

${ }^{39}$ Aul, supra note 9 , at 102.
} 
in a state of helplessness. Many victims begin to respond overcautiously and oversensitively to their environment, because the perpetrator could appear anywhere and at any time. ${ }^{40}$

The psychological pressure that is put on stalking victims can result in various mental health problems, such as nervousness, ${ }^{41}$ depression, anxiety, neuroses, and post-traumatic stress disorder. ${ }^{42}$ In addition, other impairments to one's health that are typically associated with stalking - including nightmares, gastro-intestinal diseases, and cardiovascular conditions-might occur. ${ }^{43}$ This intense mental, and often also physical, stress is equally-and, in some cases, even more-distressing to the victim, and therefore should be deemed culpable independently of compelling the victim to display certain behavior. ${ }^{44}$

\section{Social and Economic Pressure on the Victims}

Furthermore, attention should be paid to the fact that the victim's outward behavior does not always properly indicate the extent of emotional stress that they could be suffering. ${ }^{45}$ Neither the criminal behavior itself nor the crime's intensity can be considered exclusive causes for the victim's reactions, because other factors, such as the victim's personality and living conditions, play a vital role as well.

One factor that can massively impair the victim's ability to react properly is the perpetrator's personal attachment to the victim. While some perpetrators are a part of the victim's environment as friends, colleagues, neighbors, or clients, ${ }^{46}$ up to fifty percent of all documented stalking cases are believed to be committed by former intimate partners potentially trying to win the victim back. ${ }^{47}$ The latter constellation is particularly problematic because ex-partners tend to be especially familiar with their victim's environment, lifestyle habits, and regular activities. Therefore, a victim would be forced to undergo dramatic changes regarding every part of their life in order to entirely avoid the perpetrator.

Additionally, social, economic, and occupational pressure often hinder a victim from altering their way of life in order to avoid the perpetrator. Living with limited financial resources, or the social situation in general, often leaves very limited options for changing personal living conditions. ${ }^{48}$ In extreme cases, a victim in already precarious financial situations could be forced to change their job or to finance costly relocations, only to prove to the court that their lifestyle has been seriously infringed upon. ${ }^{49}$ Generally, these actions inevitably go hand in hand with financial losses, which can be devastating to a victim with no financial reserves.

This social and financial predicament particularly applies to women, as they are not only more likely to fall victim to stalking than men, but also tend to have responsibility for other family members, take care of children, or are obliged to look after care-dependent relatives. ${ }^{50}$ In a situation like this, behavior deemed adequate by the legislature and the judiciary, such as social withdrawal or relocation, will be extremely difficult to put into practice. ${ }^{51}$

\footnotetext{
${ }^{40}$ AuL, supra note 9 , at 102.

${ }^{41}$ AUL, supra note 9, at 102.

${ }^{42}$ Heinz Schöch, Zielkonflikte beim Stalking-Tatbestand, Neue ZeITSChrift FÜr STRAFrecht 221, 222 (2013).

${ }^{43} I d$. at 222 .

${ }^{44}$ Cabinet Draft 193/14 at 5 .

${ }^{45}$ Susanne Beck, Wie besonnen muss ein Stalking-Opfer sein?, 159 GOLTDAMMER's ARCHIV FÜr STRAFRECHT 722, 724-725 (2012).

${ }^{46}$ Aul, supra note 9 , at 97.

${ }^{47}$ Aul, supra note 9 , at 95 .

${ }^{48}$ Cabiet Draft $193 / 14$ at 6.

${ }^{49}$ Urs KindHäUSER ET AL., STRAFGESETZBUCH $₫ 238$ para. 45 (2017).

${ }^{50}$ Cabinet Draft $193 / 14$ at 6.

${ }^{51}$ Schöch, supra note 42, at 223.
} 


\section{Exclusion of Unperturbed Victims}

Although victims might differ in the way that they perceive and deal with external pressure, the Bundesgerichtshof (German Federal Court of Justice) states that the elements of the crime of $\$ 238$ StGB should neither protect overanxious victims nor ignore victims that remain largely unaffected by the perpetrator's actions. ${ }^{52}$ Nevertheless, there is no obvious reason why some victims should not be protected against such encroachments simply because they are, at least temporarily, able to withstand greater pressure.

The protection of victims who decide to stand up to the perpetrator's stalking could be particularly significant, because the unperturbed nature of their behavior is more likely to contribute to a de-escalation of the situation. In specialized literature, the method that is commonly recommended to end stalking is not only to ignore the perpetrator's harassment and attempts to establish contact, but also to keep the perpetrator in suspense about whether their actions manage to affect the victim or not..$^{53}$ Regardless, because $\$ 238$ StGB demands an outward reaction from the victim, this de-escalating behavior cannot fulfill the elements of the crime.

Consequently, the behavior that the drafting of $\$ 238$ StGB demands from the victim in order to fulfill the elements of the crime-changing one's living conditions and giving in to the perpetrator-is exactly the kind of behavior that should be avoided. Therefore, the former version of $\$ 238$ StGB ultimately accomplishes what the perpetrator maybe could not achieve: Swaying the victim's will.

\section{E. The New Legislation from 2017}

By introducing the Gesetz zur Verbesserung des Schutzes gegen Nachstellungen (Act for the Improvement of the Protection Against Stalking), ${ }^{54}$ which has been in effect since March 1, 2017, the basic structure of $\$ 238$ StGB was adjusted. Previously, criminal responsibility under this law required the achievement of a certain result, therefore $₫ 238$ StGB was, as mentioned above, classified as an Erfolgsdelikt (result crime). Under the new legislation, an act that merely infringes the victim's lifestyle-regardless of the outcome-may be sufficient to warrant a criminal offense. Section $238 \mathrm{StGB}$ is, therefore, now classed as an Eignungsdelikt (suitability crime).

\section{Classification as a Eignungsdelikt and Legal Policy}

What is distinctive for the elements of suitability crimes is the lack of requirement for a result from the perpetrator's action. As such, a perpetrator is criminally liable by committing the respective action. Therefore, the potential point of criminal liability is, temporally speaking, moved forward. ${ }^{55}$

The decision to gradually accept more elements of a crime without necessitating a result of the perpetrating action has been long since criticized, especially as part of a discussion held in respect of the term Risikostrafrecht (criminal risk law) ${ }^{56}$ In the eye of new risks inherent to modern society, some scholars state that criminal law needs to adapt to those risks. ${ }^{57}$ Critics fault the trend towards such a criminal risk law because it leads to an inappropriate extension of criminal liability and an increasing reliance upon subjective, rather than objective, aspects as the grounds

\footnotetext{
${ }^{52}$ Bundesgerichtshof [BGH] [Federal Court of Justice] 54, 189, 197.

${ }^{53}$ Cabinet Draft $193 / 14$ at 7.

${ }^{54}$ Gesetz zur Verbesserung des Schutzes gegen Nachstellungen [Act for the Improvement of the Protection Against Stalking], Mar. 1, 2017, BGBL I at 386-387 (Ger.).

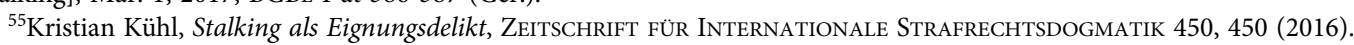

${ }^{56}$ Cornelius PritTWitZ, STRAFreCht UNd Risiko 364-386 (1993); ZACHARIAS, supra note 14, at 345-347

${ }^{57}$ Claus Roxin, Strafrecht Allgemeiner Teil Band I, $\$ 2$ para. 71 (2006).
} 
for criminal responsibility. ${ }^{58}$ Facing the threat of punishment as early as possible-prior to any result of the perpetrator's actions - intensifies the impact on the rights of the individual, thus requiring the legally protected interest to be adequately essential.

Section 238 StGB is supposed to protect the victim's mental welfare and, therefore, aims to ensure the absence of fear. ${ }^{59}$ Because fear inflicted by the perpetrator's actions does not necessarily culminate in the victim changing their lifestyle-be it for want of pecuniary resources or out of fear-the protection of mental welfare through $\$ 238$ StGB would be insufficient if it were restricted to cases in which there were a significant change to the victim's lifestyle. From the standpoint of legal policy, the extension of criminal liability in general is judicious.

\section{Dogmatic Justification}

The principle of proportionality is an equally as substantial a justification for the novel arrangement of $₫ 238$ StGB. It encompasses the aspects of suitability for a legitimate purpose, necessity, and appropriateness. ${ }^{60}$

\section{Suitability for the Protection of the Respective Legal Interests}

For the new arrangement to comply with this fundamental principle, it would have to be beneficial with regard to its purpose. ${ }^{61}$ By extending the scope of criminal liability, including cases in which no result emerged from the respective actions, the new edition of $\S 238$ StGB facilitates the prosecution of offenders. ${ }^{62}$ Thereby, the new legislation is fit to support the protection of mental welfare and thus benefits its purpose.

\section{Necessity}

Furthermore, the principle of proportionality postulates that there shall be no other milder means that are equally efficient. ${ }^{63}$ Particularly relevent in this connection is the principle of criminal law as the last resort, the ultima ratio, thus only to be utilized if no other means from civil or public law are equally appropriate and promising. ${ }^{64}$ Admittedly, there are alternative means, especially those set out in the Gewaltschutzgesetz, injunction orders pursuant to $\$ 1004$ of the German Civil Code (BGB), and measures taken by the police in order to ward off danger. ${ }^{65}$ The efficiency of these means is, however, somewhat questionable. ${ }^{66}$

In this respect, the aforementioned means cannot be assumed-without further inspection-as being equal or more promising for the protection against stalking. Therefore, the necessity of the new law cannot be negated on this line of reasoning.

\section{Appropriateness}

The new arrangement and its consequences would have to be reasonably proportionate to its purpose. ${ }^{67}$ Therefore, the previous discussion concerning criminal risk law should be

\footnotetext{
${ }^{58}$ Detlev Frehsee, Die Strafe auf dem Prüfstand, STRAFVERTEIDIGER 223, 227 (1996).

${ }^{59}$ Wolfgang Mitsch, Der neue Stalking-Tatbestand im Strafgesetzbuch, NeUE JURISTISCHE WOCHENSCHRIFT 1237, 1237 -1238 (2007); Jörg Kinzig, Stalking - ein Fall für das Strafrecht?, 39 ZEITSCHRIFT FÜr RECHTSPOLITIK 255, 257 (2006).

${ }^{60}$ Hans Jarass \& Bodo Pieroth, Grundgesetz Für die Bundesrepublik Deutschland Kommentar art. 20 para. 116 (15th ed. 2018).

${ }^{61}$ BVerfGE 126, 112 (144).

${ }^{62}$ ZACHARIAS, supra note 14 , at 357.

${ }^{63}$ BVerfGE 102, 197 (217)

${ }^{64}$ BVerfGE 39, 1 (47)

${ }^{65}$ Frank Meyer, Strafbarkeit und Strafwürdigkeit von „Stalking” im deutschen Recht, 115 ZEITSCHRIFT FÜR DIE GESAMTE STRAFRECHTSWISSENSCHAFT 249, 290-291 (2008).

${ }^{66}$ Monika Frommel, Zähne zeigen - unter welchen Bedingungen funktioniert ein zivilrechtlicher Rechtsschutz gegen häusliche Gewalt?, KRITISCHE JUSTIZ 82, $82 \mathrm{f}$ (2002).

${ }^{67}$ BVerfGE 100, 313 (375 f.).
} 
addressed. Some see the new law as inappropriate because it enables acts that are socially generally acceptable to form the basis of criminal liability. ${ }^{68}$ This line of argumentation, however, is not convincing, as the acts only then constitute the basis for liability if the sum of the combined multiple acts-and their impact on the victim-lead to a criminal act. ${ }^{69}$ Section 238 StGB includes the element of Beharrlichkeit (persistence), which further differentiates between those acts which will lead to criminal responsibility from those which will be assessed as socially acceptable.

\section{Compliance with the Principle of Legal Certainty}

Concerning the general question as to whether $₫ 238$ StGB conforms to the principle of legal certainty, there has been one major issue in the legislative process. Critics believe that criminal liability may be excessively extended and find the lack of precision problematic. Therefore, it was intended in the draft from October 12, 2016, to strike out the general clause- $\$ 238$ I No. 5 StGBencompassing any similar acts to those mentioned in the numbers before. ${ }^{70}$ Because this clause was not struck out in the final version, it might be reasonable to rebuke the fact that criminal liability is extended not only by waiving the element of a required result, but furthermore, by leaving the general clause unchanged.

Nevertheless, the general clause's necessity is based upon the variety of acts which can be considered to be stalking; a variety which cannot be confined to a manageable number of single, precise forms of behavior. ${ }^{71}$ In fact, through $₫ 238$ I No. $5 \mathrm{StGB}$, the courts are able to adjust to new forms of stalking, which may not have been mentioned yet in numbers one through four. ${ }^{72}$

\section{F. Additional Changes}

The changes made by the legislature were not, however, limited to the StGB. Germany's Code of Criminal Procedure (Strafprozessordnung; StPO) and the Gewaltschutzgesetz have also been amended, as has the introduction of a new section in the Act on Proceedings in Family Matters and in Matters of Non-contentious Jurisdiction (Gesetz über das Verfahren in Familiensachen und in den Angelegenheiten der freiwilligen Gerichtsbarkeit; FamFG).

\section{Amendment of $\S 374$ StPO $^{73}$}

\section{Privatklage (Private Prosecution)}

In accordance with the principle of ex-officio prosecution (Offizialmaxime), only the prosecution service may institute legal proceedings, and, pursuant to the principle of compulsory prosecution (Legalitätsprinzip), it is compelled to do so under $₫ 152$ StPO. ${ }^{74}$ Yet, if the prosecutor concludes that there is no sufficient interest in pressing public charges, the proceedings may be stayed, and the aggrieved party is entitled to commence a private prosecution for offenses specified in $\$ 374$ StPO.

\footnotetext{
${ }^{68}$ SADTLER, supra note 6 , at 322.

${ }^{69}$ ZACHARIAS, supra note 14 , at 362 .

${ }^{70}$ Regierungsentwurf [Cabinet Draft] Deutscher Bundestag: Drucksachen [BT] 18/9946, at 2 (Ger.) [hereinafter Cabinet Draft 18/9946].

${ }^{71}$ SADTLER, supra note 6, at 315.

${ }^{72}$ Jörg Kinzig \& Sebastian Zander, Der neue Tatbestand der Nachstellung (\$238 StGB), JURISTISCHE ARBEITSBLÄTTER 481, 484 (2007).

${ }^{73}$ Strafprozessordnung [STPO] [CODE OF CRIMINAL Procedure], translation at www.gesetze-im-internet.de/ englisch_stpo/index.html (Ger.).

${ }^{74}$ Lutz Meyer-Goßner \& Bertram Schmitt, Strafprozessordnung: StPO $\$ 152$ para. 1-2 (63rd ed. 2020).
} 
The aggrieved party may bring a private prosecution for minor offenses only, granted that the act does not violate multiple laws at once (Tateinheit, $\$ 52$ StGB) or more than one law at the same time (Tatmehrheit, $₫ 53$ StGB), ${ }^{75}$ and that public interest is only slightly affected, if at all. ${ }^{76}$

\section{Criticism}

If the victim decides to press charges, compulsory confrontation with the offender is inevitable. Considering that the stalker typically craves attention, regardless of whether it is positive or negative, this evidently appears to be wholly deleterious. ${ }^{77}$ Furthermore, the allegedly infringed party undertakes the costs risk, including the stalker's expenses. ${ }^{78}$ Although a private prosecution is conducive to discharging the judiciary, ${ }^{79}$ shifting the conduct of criminal proceedings onto the victim circumvents the protection to which the victim should be entitled. ${ }^{80}$

\section{Removal of § 238 StGB from § 374 StPO}

With the introduction of the Act for the Improvement of the Protection Against Stalking, ${ }^{81}$ the clause eine Nachstellung oder (stalking order) was removed from $\$ 374$ I No. 5 StPO. Even though public interest is affirmed whenever the aggrieved party cannot be expected to enforce private prosecution due to the distinctive perpetrator-victim relationship, the removal fills a gap in criminal liability. ${ }^{82}$

\section{Outlook on Prospective Proceedings}

Regardless of the fact that $\$ 238$ StGB stipulates a higher maximum sentence, $₫ 4 \mathrm{GewSchG}^{83}$ constitutes an offense which is subject to ex officio prosecution. ${ }^{84}$ The amendment of $\$ 374$ StPO promotes an equal status of criminal prosecution in accordance with $₫ 238$ StGB and $\$ 4$ GewSchG. ${ }^{85}$ Furthermore, the victim does not incur the costs risk, which facilitates the enforcement of their rights.

Nevertheless, criticism has been levelled at the amendment. The Deutsche Richterbund-the German Association of Judges-emphasizes that participating in litigation is frequently crucial for the victim in order to abandon victimhood. Furthermore, borderline cases will presumably be terminated prematurely without charge and it will be difficult for the victims to obtain remedies. $^{86}$

\section{Introduction of $\S 214 a$ FamFG and Amendment of $\S 4$ GewSchG \\ 1. Significance of Out-of-Court Settlements in Stalking Cases}

If the offender and the victim reach an out-of-court settlement, the breach of the covenants assented to is not actionable, even though the victim could have applied for a binding judicial

\footnotetext{
${ }^{75} I d$. at $\$ 374$ para. 3 .

${ }^{76}$ Markus WeinitschKe, RechtsschutZ Gegen StALKING DE LEgE LATA ET FERENDA 170 (2009).

${ }^{77}$ Cabinet Draft 18/9946.

${ }^{78}$ Mosbacher, supra note 37, at 983.

${ }^{79}$ Mosbacher, supra note 37, at 983.

${ }^{80}$ WeINITSCHKE, supra note 76 , at $170-171$.

${ }^{81}$ Gesetz zur Verbesserung des Schutzes gegen Nachstellungen [Act for the Improvement of the Protection Against Stalking], Mar. 1, 2017, BGBL I at 386-387 (Ger.).

${ }^{82}$ Mosbacher, supra note 37, at 983.

${ }^{83}$ Gewaltschutzgesetz [Protection Against Violence Act], translation provided by the authors.

${ }^{84}$ Mosbacher, supra note 37 , at 983.

${ }^{85}$ Mosbacher, supra note 37 , at 983 .

${ }^{86}$ Stellungnahme zum Referentenentwurf eines Gesetzes zur Verbesserung des Schutzes gegen Nachstellungen [Advisory Opinon], Deutscher Richterbund [RB] Nr. 06/16 (Ger.) [hereinafter Advisory Opinion 06/16].
} 
order in accordance with the GewSchG. ${ }^{87}$ Nevertheless, this sort of civil action is flexible with respect to legal consequences and provides the opportunity to find an appropriate solution. ${ }^{88}$ In 2013, parties reached an out-of-court settlement in approximately twenty-five percent of stalking cases, giving out-of-court settlements considerable significance in dispute resolution. $^{89}$

\section{New Legislation}

In contemplation of filling the gap in liability, the German parliament introduced $\$ 214$ a to the FamFG $^{90}$ and amended $\S 4$ GewSchG:

\section{$\$ 214$ a FamFG: Confirmation of the Out-of-Court Settlement}

If the parties reach an out-of-court settlement, the court has to confirm it, if it could have imposed an injunction in accordance with $₫ 1$ I GewSchG or $₫ 1$ II S. 1 GewSchG. The confirmation of the court is not voidable. ${ }^{91}$

\section{$\$ 4$ GewSchG: Penal Provision}

A custodial sentence up to one year or a monetary penalty may be imposed upon an offender who ...

2. Breaches obligations consented on in an out-of-court settlement as far as this settlement ... could have been confirmed in accordance with $₫ 214$ a FamFG ... ${ }^{92}$

\subsection{Prerequisite of the Confirmation}

In order to be commensurate with the requirements of the rule of law, the court is required to revise the settlement on terms of necessity, reasonableness, and legal certainty. ${ }^{93}$ Seemingly, this would nullify the intended work relief for the courts. ${ }^{94}$ Yet, if the requirements are met, the court can confirm the out-of-court settlement insofar as it could have imposed an injunction; a formal rejection is not necessary. ${ }^{95}$

\footnotetext{
${ }^{87}$ Cabinet Draft $18 / 9946$.

${ }^{88}$ Advisory Opinion $06 / 16$.

${ }^{89}$ Mosbacher, supra note 37, at 983.

${ }^{90}$ Gesetz über das Verfahren in Familiensachen und in den Angelegenheiten der freiwilligen Gerichtsbarkeit [Act on Proceedings in Family Matters and in Matters of Non-contentious Jurisdiction], Dec. 17, 2008, BGBL I at 2586, 2587, last amended by Gesetz [G], June 22, 2019, BGBL I at 866, (Ger.), www.gesetze-im-internet.de/englisch_famfg/index.html.

${ }^{91}$ Gesetz über das Verfahren in Familiensachen und in den Angelegenheiten der freiwilligen Gerichtsbarkeit [FamFG] [Act on Proceedings in Family Matters and in Matters of Non-contentious Jurisdiction], Dec. 17, 2008, BGBL I at 2586, 2587, last amended by Gesetz [G], June 22, 2019, BGBL I at 866, art. 2 (Ger.), https://www.gesetze-im-internet.de/englisch_famfg/ englisch_famfg.html\#p1082 (214a FamFG: "Schließen die Beteiligten einen Vergleich, hat das Gericht diesen zu bestätigen, soweit es selbst eine entsprechende Maßnahme nach $\$ 1$ Absatz 1 des Gewaltschutzgesetzes, auch in Verbindung mit $\$ 1$ Absatz 2 Satz 1 des Gewaltschutzgesetzes, hätte anordnen können. Die Bestätigung des Gerichts ist nicht anfechtbar." (translation provided by the authors)).

${ }^{92}$ Mit Freiheitsstrafe bis zu einem Jahr oder mit Geldstrafe wird bestraft, wer einer bestimmten vollstreckbaren ( . . .) 2 . Verpflichtung aus einem Vergleich zuwiderhandelt, soweit der Vergleich nach $\$ 214 \mathrm{a}$ Satz 1 des Gesetzes über das Verfahren in Familiensachen und in den Angelegenheiten der freiwilligen Gerichtsbarkeit (...) bestätigt worden ist (...)., (translation provided by the authors).

${ }^{93}$ Michael Cirullies \& Birgit Cirullies, Das neue Gesetz zur Verbesserung des Schutzes gegen Nachstellungen, 7 ZEITSCHRIFT FÜR DAS GESAMTE FAMILIENRECHT 493, 493ff (2017).

${ }^{94}$ Bundesverband Frauenberatungsstellen und Frauennotrufe, bff-Stellungnahme zum Gesetz zur Verbesserung des Schutzes gegen Nachstellungen.

${ }^{95}$ Cirullies \& Cirullies, supra note 94 , at $493 \mathrm{ff}$.
} 


\subsection{Imposing an Application Requirement}

A mandatory punishment could diminish the readiness of the perpetrator to agree to the settlement. ${ }^{96}$ An application to the court would allow the parties to be more flexible. ${ }^{97}$ Nevertheless, anguish might deter the victim from applying and would push them back into the role of the aggressor directly after a settlement has been reached. Therefore, this decision should not be imposed upon the victim. ${ }^{98}$

\section{G. Outlook}

In conclusion, the above-mentioned changes will most certainly result in a higher conviction rate and thus would further aid victims of stalking. Whereas, prior to these amendments, the injured person could not be reassured that the prosecution would represent their interests in court, now the focus has clearly shifted to the protection of the victim. The legislation strived to improve the law and eliminate all issues involved in combating stalking. Nevertheless, problems such as the vagueness of the wording-especially of $\$ 238$ I No. 5 StGB - have not yet been fully addressed.

It is to be expected that the German Federal Constitutional Court will have to adjudicate on the constitutionality of the new legislation. Only its application will demonstrate whether all issues regarding criminal proceedingsbased on stalking have been remedied and whether this new method will be successful.

\footnotetext{
${ }^{96}$ Cabinet Draft 18/9946; Cirullies \& Cirullies, supra note 94, at $493 \mathrm{ff}$.

${ }^{97}$ Cabinet Draft 18/9946 at 17-18(Statement of the Federal Council (Bundesrat)).

${ }^{98}$ Cabinet Draft 18/9946.
} 